\title{
Fostering Information Literacy Development: A Case Study of the Management Major at the U.S. Coast Guard Academy
}

\author{
Alina M. Zapalska, Ben Wroblewski \\ U.S. Coast Guard Academy, USA
}

\begin{abstract}
This paper illustrates the information literacy strategy in an undergraduate Management program at U.S. Coast Guard Academy. The paper exemplifies a sequential approach that improves students' capabilities to evaluate and apply information in a specifically designed learning environment while generating new knowledge in undergraduate business coursework. The paper also emphasizes how IL can be developed within management coursework through a six-step process, including defining, locating, selecting, organizing, presenting, and assessing. This specially designed framework of IL learning can be applied across all relevant courses using specially designed assignments in the Management major.
\end{abstract}

\section{Introduction}

Information Literacy (IL) has been recognized as a vital learning outcome and a lifelong learning skill [7], [9], [11]. In Information Literacy Competency Standards for Higher Education, the Association of College and Research Libraries (ACRL) [2] developed accreditation standards to respond to the challenges of enhancing IL initiatives. As a result, IL education is considered as a standard pedagogical instrument that improves students' IL capabilities while mastering required subject [4], [8]. As today's IL instruction is no longer confined to traditional library instruction [5], [9], academic programs create opportunities for independent learning where students use numerous information sources to develop and master their specific skills or knowledge [10], [12]. In response to this challenge, the ACRL established the ACRL Information Literacy Competency Standards for Higher Education and a definition of an IL person [2]. Those IL standards emphasize finding and selecting appropriate information, and critically evaluating the use of information to produce understanding and application of new knowledge. Development of those IL skills must also allow students to complete their IL tasks effectively, legally, and ethically [1]. This paper presents how the IL strategy is used in an undergraduate program of the Management Department at U.S. Coast Guard Academy (USCGA). The attainment of the IL educational goals is based on the ACRL [2] definitions and assessment outcomes. The paper begins with an overview of IL process within the undergraduate management coursework at USCGA. The paper provides an example of an IL assignment framework that is implemented across selected management coursework.

\section{Information Literacy Education in the USCGA}

The USCGA is a public institution that provides an academic undergraduate education as well as physical and military training to the cadets who will serve as leaders in the United States Coast Guard (USCG). The Academy's mission is to: educate, train, and develop leaders of character who are ethically, morally, intellectually, and professionally prepared to serve their country and humanity. In order to meet these goals, the Academy's holistic education delivers academic, physical fitness, ethical, character and leadership development programs. As military professionals, the USCGA cadets are expected to be responsible for their own behavior, hold others accountable, and to display devotion to the mission of the USCG and the Department of Homeland Security. The Academy provides undergraduate academic coursework that is supported through required courses within humanities, science, engineering, mathematics, maritime studies, organizational behavior, management, and law. The Department of Management at USCGA delivers an undergraduate management education where Management majors are expected to develop and master business competencies, communication, self-leadership, critical thinking, and information literacy skills. These skills, as illustrated in Table 1, are closely related to the shared learning outcomes across all majors at USCGA.

The CGA Management department recognizes that IL skills are critical to the success of the Coast Guard as an organization. The Academy requires all graduating cadets to understand and fully adapt to the characteristics of the information age. The IL strategy has been developed with the assistance of the librarian staff who implemented training sessions across the USCGA curriculum. Table 2 presents a list of courses that are currently involved with specially designed IL training elements across all majors during four years of undergraduate study at USCGA. 
Table 1. The USCG Academy and Management Department Learning Goals

\begin{tabular}{|c|c|}
\hline $\begin{array}{l}\text { United States Coast Guard Academy } \\
\text { Shared Learning Outcomes }\end{array}$ & $\begin{array}{l}\text { Department of Management } \\
\text { Learning Outcome Areas }\end{array}$ \\
\hline $\begin{array}{l}\text { Leadership Abilities: Graduates shall be military and civilian } \\
\text { leaders of character who understand and apply sound } \\
\text { leadership principles and competencies. This includes the } \\
\text { ability to direct, develop, and evaluate diverse groups; to } \\
\text { function effectively and ethically as a leader, follower, } \\
\text { facilitator or member of a team; and to conduct constructive } \\
\text { assessment of self and others. }\end{array}$ & $\begin{array}{l}\text { Leadership: Graduates of the Management major } \\
\text { shall be leaders of character who understand and } \\
\text { demonstrate sound leadership principles and } \\
\text { competencies. Graduates shall function effectively as } \\
\text { leaders, followers, and facilitators. Graduates shall be } \\
\text { able to conduct critical self-reflection and } \\
\text { assessment. Graduates shall be able to direct, } \\
\text { develop, and evaluate diverse individuals and groups. }\end{array}$ \\
\hline $\begin{array}{l}\text { Personal and Professional Qualities: Graduates shall } \\
\text { maintain a professional lifestyle that embraces the Coast } \\
\text { Guard Core Values of Honor, Respect and Devotion to Duty, } \\
\text { includes physical fitness and wellness, and demonstrates the } \\
\text { customs, courtesies and social skills befitting members of a } \\
\text { maritime military service. Graduates shall also have a sense } \\
\text { of Coast Guard maritime heritage and an understanding of } \\
\text { the roles that the Coast Guard and the nation play in the } \\
\text { global environment. }\end{array}$ & $\begin{array}{l}\text { Information Literacy: Graduates of the Management } \\
\text { major shall be leaders who possess the ability to } \\
\text { know when there is a need for information, to be able } \\
\text { to identify, locate, evaluate and effectively use that } \\
\text { information for the issue or problem at hand. }\end{array}$ \\
\hline $\begin{array}{l}\text { Communication Effectiveness: Graduates shall be able to } \\
\text { write clearly, concisely, persuasively, and grammatically; } \\
\text { prepare and deliver well-organized and polished oral } \\
\text { presentations; read and understand a variety of written } \\
\text { materials; listen thoughtfully to oral arguments; respect } \\
\text { diverse opinions; and formulate reasoned alternatives and } \\
\text { responses. }\end{array}$ & $\begin{array}{l}\text { Communication: Graduates of the Management } \\
\text { major shall be good listeners. Graduates shall be able } \\
\text { to write clearly, concisely, and effectively. Graduates } \\
\text { shall be able to deliver effective practiced, } \\
\text { professional oral presentations and be able to speak } \\
\text { confidently extemporaneously. }\end{array}$ \\
\hline $\begin{array}{l}\text { Ability to Acquire, Integrate and Expand Knowledge: } \\
\text { Graduates shall have developed the motivations and skills } \\
\text { for "lifelong learning." Graduates shall be able to create a } \\
\text { working conceptual framework that lends itself to continued } \\
\text { expansion. To accomplish this, graduates shall be able to } \\
\text { efficiently access a broad range of information sources, } \\
\text { locate and interpret desired data reliably, employ } \\
\text { appropriate technology, and integrate knowledge. } \\
\text { Graduating cadets shall also have acquired and integrated } \\
\text { the specific in-depth knowledge required of both an } \\
\text { academic major and an entry-level professional assignment. } \\
\text { The Leadership Development Center course graduates shall } \\
\text { have accomplished all program objectives. }\end{array}$ & $\begin{array}{l}\text { Business Competence: Graduates of the Management } \\
\text { major shall understand and demonstrate the } \\
\text { following business competencies: (a) accounting, (b) } \\
\text { economics, (c) management, (d) quantitative analysis, } \\
\text { (e) finance, (f) marketing, (g) international issues, (h) } \\
\text { legal and social environment issues, and (i) } \\
\text { management of information systems. }\end{array}$ \\
\hline $\begin{array}{l}\text { Critical Thinking Ability: Graduates shall be able to } \\
\text { accomplish complex tasks in a broad range of contexts by } \\
\text { applying the basic skills of critical analysis, systems thinking, } \\
\text { quantitative reasoning, risk management, creative problem } \\
\text { solving, and value-based decision-making. }\end{array}$ & $\begin{array}{l}\text { Critical Thinking: Graduates of the Management } \\
\text { major shall be able to effectively integrate their } \\
\text { knowledge and skills of/in leadership, } \\
\text { communications, technology, and business } \\
\text { competencies into a rational decision-making and } \\
\text { problem-solving framework. }\end{array}$ \\
\hline
\end{tabular}

Source: Developed by Department of Management, USCGA

Table 2. A List of Courses Included in the IL Education

American Government

American Social Movements

Civil Engineering Design

Coast Guard History

Design Project Management

English Composition and Speech

Environmental Engineering

Ethnic Literature in the US

Gender and Sexual Orientation in Literature

Intelligence and Cyber Operations

Intro to Mechanical Engineering Design

Introduction to Business

Introduction to Latin American Studies

Literature of Humanity and Conflict: African-

American Literature
Principles of Macroeconomics

Management Information Systems

Marine Engineering

Maritime Watch Officer

Marketing

National Security Policy

Ocean Dynamics

Operations Analysis

Organizational Behavior and Leadership

Petroleum and Oil Spill Science

Physics I and II

Principles of Ship Design

Reinforced Concrete Design

Social Science Research Methods

Soil Mechanics

Source: Management Department, the U.S. Coast Guard Academy 
The Management department at USCGA develops IL skills across its curriculum in addition to all other IL training included in other nonmanagement courses. The goal is to advance IL skills progressively throughout all four years of an undergraduate program as illustrated in Figure 1. Those courses highlighted have specially designed assignments to advance IL skills.

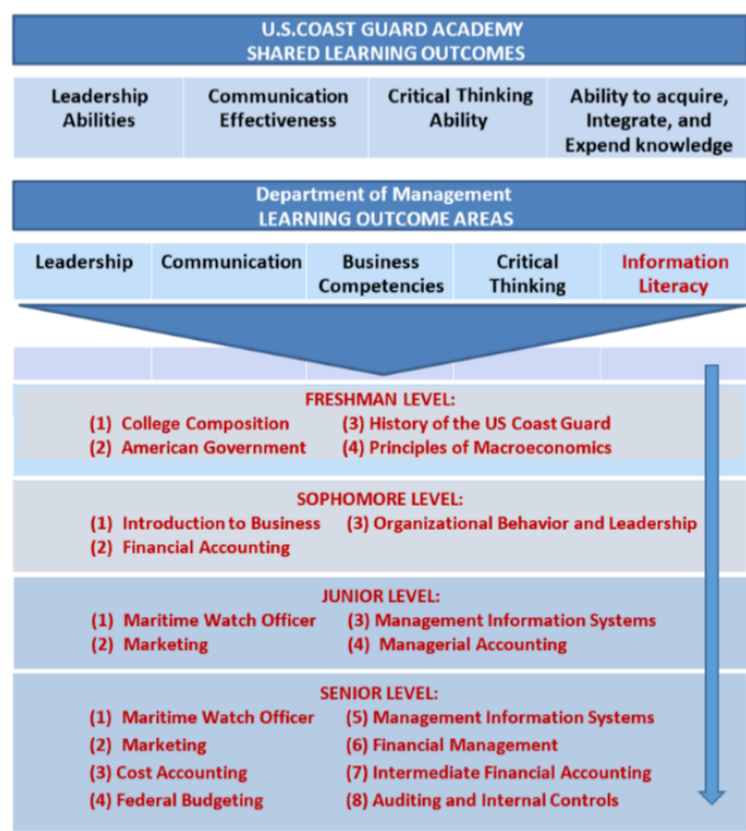

Figure 1. Management Department at U.S. Coast Guard Academy Shared Learning Outcome and Information Literacy

(Source: Management Department, the U.S. Coast Guard Academy)

The Management department faculty has used the ACRL Information Literacy Competency Standards for Higher Education. According to the ACRL definition, an information literate person is defined as someone who can: (1) determine the extent of information needed; (2) access the needed information effectively and efficiently; (3) evaluate information and its sources critically; (4) use information effectively to accomplish a specific purpose; and (5) obtain and use information ethically and legally (Association of College and Research Libraries, 2000). IL education in the Management Department must guarantee that those skills are developed across the curriculum so that every graduating student becomes IL competent as defined by the ACRL. In order to integrate IL across the Management curriculum, faculty must recognize that it is critical to identify potential courses each year for IL integration. IL must be integrated into the course content, assignments, and the course lectures. In particular, the integration of IL in coursework projects enables students to recognize when information is needed and to develop a capacity to locate and use information effectively as stated in the intended assignment. IL must be integrated into the course objectives and class activities where the objectives of the course introduce students to new methods of gathering, processing, and presenting information. The IL competencies are targeted expectations for freshman, sophomore, junior, and senior levels as presented in Figure 2.

\begin{tabular}{|c|c|c|c|c|}
\hline IL Outcomes & $\begin{array}{l}\text { Baseline } \\
\text { Novice }\end{array}$ & $\begin{array}{l}\text { Progressing } \\
\text { Apprentice }\end{array}$ & $\begin{array}{l}\text { Proficient } \\
\text { Journeyman }\end{array}$ & $\begin{array}{l}\text { Distinguished } \\
\text { Master }\end{array}$ \\
\hline $\begin{array}{l}\text { Determine the Extent of } \\
\text { Information Needed }\end{array}$ & \multirow{5}{*}{$\begin{array}{c}F \\
R \\
E \\
S \\
H \\
M \\
A \\
N\end{array}$} & \multirow{5}{*}{$\begin{array}{l}\mathrm{S} \\
\mathrm{O} \\
\mathrm{P} \\
\mathrm{H} \\
\mathrm{O} \\
\mathrm{M} \\
\mathrm{O} \\
\mathrm{R} \\
\mathrm{E}\end{array}$} & \multirow{5}{*}{$\begin{array}{l}\mathrm{J} \\
\mathrm{U} \\
\mathrm{N} \\
\mathrm{I} \\
\mathrm{O} \\
\mathrm{R}\end{array}$} & \multirow{5}{*}{$\begin{array}{l}\text { S } \\
\text { E } \\
N \\
\text { I } \\
\text { O } \\
\text { R }\end{array}$} \\
\hline $\begin{array}{l}\text { Access the Needed } \\
\text { Information }\end{array}$ & & & & \\
\hline $\begin{array}{l}\text { Evaluate Information and } \\
\text { Sources Critically }\end{array}$ & & & & \\
\hline $\begin{array}{l}\text { Use Information Effectively to } \\
\text { Accomplish a Specific Purpose }\end{array}$ & & & & \\
\hline $\begin{array}{l}\text { Obtain and use Information } \\
\text { Ethically and Legally }\end{array}$ & & & & \\
\hline
\end{tabular}

Figure 2. The US Coast Guard Academy IL

Competences by Academic Grade

(Source: Developed by the IL Committee at U.S. CGA)

In the Management Department, the first IL educational step is presented by the librarians who help students find information resources for their assignments. Library staff offer tutorials that allow students to perform hands-on exercises to reinforce IL concepts that were taught during lecture. Following these exercises, students are required to complete online practice which focuses on searching and finding resources and databases. The librarians are invited to co-teach the IL concepts in order to acquaint students with how to find specific information. The course research assignments are intended to help students learn how to select and narrow an appropriate topic, conduct research, write a research paper through multiple drafts, and construct bibliographies.

They also allow students to explore in detail a specific issue within the course while effectively, ethically and legally using acquired information. Students become critical thinkers within the topics of their research papers, and they learn by applying their specific knowledge while developing a final project. The Management faculty provide IL assignments within their own courses where they expect students to develop an ability to frame research questions and locate, evaluate, manage, and use information in a required context. They also expect students to retrieve information using a variety of media; demonstrate the ability to interpret information in a variety of forms, such as written, graphs, charts, diagrams and tables; and critically evaluate information. The IL strategy or process consists of six key components with related tasks that are summarized in Figure 3. 


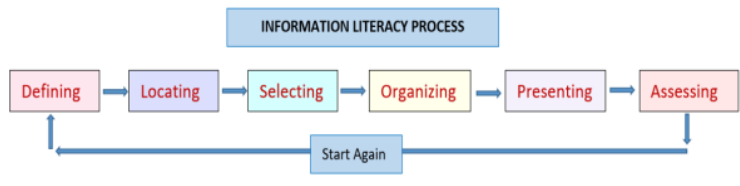

Figure 3. IL Process

(Source: Based on New South Wales Department of Education and Communities Model: Creative Commons, 2011: https://pepechick63.wordpress.com/informationliteracy/)

The six elements or steps of the IL process include defining, locating, selecting, organizing, presenting, and assessing which must be demonstrated across a four-year undergraduate program when students complete IL tasks. Every year, students are expected to progress through this six-stage framework and are expected to improve their IL skills over four years. As a result, at the senior level students must acquire the essential understanding of the locating and accessing issues, the research process, critical thinking and evaluation of information, citation, and documentation. The intent is that their senior projects will demonstrate all these abilities.

Pedagogical approaches to all teaching students how to find and evaluate sources are individualized across the disciplines involved. The essentials how to find and evaluate sources are addressed through lectures, library discussions and visits, and in-class writing workshops. For example, in introductory courses, such as Macroeconomics Principles, in-class and library-assisted workshops illustrate the differences between research and popular sources of information. In this course, students must produce a research assignment while using a range of library and electronic sources focused on the development of a thesis statement and proper documentation using a formal editorial style. At this IL level, these research writing assignments can be challenging when students are expected to examine a range of academic and popular sources as they process and develop their own written responses.

In more advanced courses, students start understanding the complex nature of information within other techniques. Students can gain significant insights about IL through their own creation of information in writing assignments. These insights can result from learning opportunities that go beyond lectures or library instruction and require students to make decisions regarding the information they select, organize, apply, and assess while completing term papers. Active learning assignments in research, writing, oral or visual presentation can also challenge students to engage in critical analysis and evaluation of information that is collected and applied. The Management faculty commonly use short papers that examine specific sources, such as a scholarly journal article, or assignments that require students to compare the structure and content of scholarly and popular sources.

\section{Structuring IL Assignments in Management Coursework}

Figure 4 presents a detailed IL process that has been used while structuring assignments, term papers or small research projects in Management Department coursework.

\section{INFORMATION LITERACY PROCESS FOR STRUCTURING ASSIGNMENTS, PAPERS, AND RESEARCH PROJECTS}

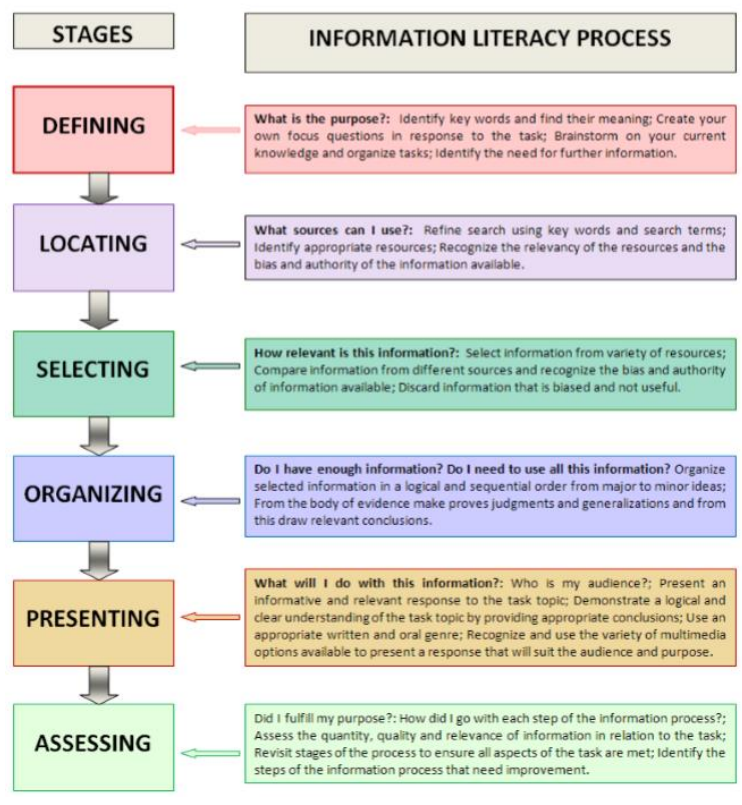

Figure 4. IL Process Description for Structuring

Assignments, Papers, and Research Projects

(Source: Management Department, the U.S. Coast Guard Academy)

The IL process begins with the students defining their project topic. They conduct a literature review where they locate credible sources that pertain to their overall project topic. Faculty then provide feedback to the students on the quality of the literature review including the relevancy, credibility, and reliability of the data and sources presented. The information from the literature review is then used to properly scope their project considering expectation and needs. After selecting the appropriate sources of information, students move forward with relevant and applicable documents and articles. Then, the students interpret and synthesize the information to produce specific recommendations. Finally, they utilize frameworks to organize the data and present in a logical format. Once they complete their assignments, students are expected to present their projects to interested parties and USCGA faculty. 
Throughout the entire process and during the presentation phase, students are assessed by peers and faculty given regarding the quality, clarity, and relevancy of their work. This completes the IL cycle for the course. The entire process uses multiple iterations of the IL cycle and ensures high quality work projects from the student groups. This IL skills process can be designed and integrated into assignments and collaborative research projects during all four years of study.

\section{Assessment of IL Development}

The IL assessment initiative includes both direct and indirect means of assessments. There are several assessment methods discussed in literature and the recommended tools include checklists, rubrics, conferencing, portfolios, reports, oral and written examinations, and other approaches [6]. Assessing IL progress is a major component of IL process at USCGA. The IL skills assessment of individual student learning is completed across selected and designated courses. This assessment process is effective in improving and advancing IL competences among students. The use of a rubric assessment of IL is a valuable tool for both USCGA librarians and faculty seeking to demonstrate evidence of students' learning.

Table 3. Assessment of IL Skills

\begin{tabular}{|c|c|c|c|c|c|c|c|}
\hline \multirow{3}{*}{$\begin{array}{c}\begin{array}{c}\mathrm{N} \\
\text { outcomes }\end{array} \\
\text { Know }\end{array}$} & \multirow[t]{2}{*}{ IL SKILIS CHARACTERISTICS } & \multicolumn{3}{|c|}{$\begin{array}{l}\text { Learner's } \\
\text { If-evaluation }\end{array}$} & \multicolumn{3}{|c|}{$\begin{array}{l}\text { Teacher's } \\
\text { Evaluation }\end{array}$} \\
\hline & & \multicolumn{6}{|c|}{ (Circle one for each stage) } \\
\hline & $\begin{array}{l}\text { Determines the nature and extent of } \\
\text { information needed }\end{array}$ & D & c & E & D & c & E \\
\hline Access & $\begin{array}{l}\text { Efficiently and effectively accesses information } \\
\text { sources }\end{array}$ & D & c & E & D & c & E \\
\hline $\begin{array}{l}\text { Evaluate } \\
\text { Sources }\end{array}$ & Critically evaluates information sources & D & c & E & D & c & E \\
\hline $\begin{array}{l}\text { Evaluate } \\
\text { Content }\end{array}$ & $\begin{array}{l}\text { Critically evaluates information content; } \\
\text { Considers impact on student's prior knowledge, } \\
\text { value system, and future direction in life }\end{array}$ & D & c & E & D & c & E \\
\hline Use & $\begin{array}{l}\text { Uses information found to accomplish a specific } \\
\text { purpose }\end{array}$ & D & c & E & D & c & E \\
\hline $\begin{array}{l}\text { Ethically } \\
\text { Legally }\end{array}$ & $\begin{array}{l}\text { Understands the economic, legal, and social } \\
\text { issues surrounding the acquisition and use of } \\
\text { information }\end{array}$ & D & c & E & D & c & E \\
\hline
\end{tabular}

The instrument to assess IL development in Table 3 illustrates the Academy's progressive approach on developing IL skills and assessing them. For example, in first year students perform IL skills at a Developing level, in sophomore year at a Developing/Competent level, in junior year at a Competent/Exemplary level, and in senior year at an Exemplary level. The goal is to implement this instrument across all other Management courses at the USCGA. This instrument is being used by instructors in selected management courses which focus on IL skills development. The instrument is designed to be used at every stage of students' progression with their homework or term project.

\section{Conclusions}

The Management Department at the USCGA recognizes the challenge of today's research; it is critical to know how to find, organize, and evaluate the validity of information available. IL exercises allow students to learn how to select the best information for their research. The USCGA IL educational competences are based on ACRL outcomes. Through specifically designed IL strategies, the faculty established the learning environment that encouraged students to explore the unknown sources of information. The faculty and specially trained librarian staff are expected to provide guidance and to monitor students' progress throughout four years of instruction. Curriculum was structured to introduce IL learning opportunities from a freshman level to a senior level. The six-stage IL process was developed to enable students to master IL skills. Those stages include defining, locating, selecting, organizing, presenting, and assessing. Achieving proficiency in IL requires development of fully integrated IL strategy into the curriculum's content, structure, and sequence of coursework. The importance of incorporating IL instruction within each course of any academic program serves as a complement to library IL instruction and assists with meeting the academic standards for the IL proficiency. The IL strategy that was developed benefits the students by advancing them from Developing to Exemplary level based on the ACRL standards. This paper illustrates how to develop confident, self-directed, and independent life-long learners. The academic faculty, together with the librarian instructors, face an increasing responsibility to adopt the IL structure to facilitate progressive advancement of IL through specially designed assignments, term papers, and research projects. Becoming information fluent makes individuals successful in their studies and prepares them for their lifelong learning as they learn how to navigate information to their best advantage. Other academic programs interested in improving IL skills instruction can adopt the IL development process discussed in this paper.

\section{References}

[1] American Library Association, (ALA), (2000). http://www.ala.org/acrl/standards/informationliteracycomp etency.

[2] Association of College and Research Libraries, (ACRL) (2000). Information Literacy competency standards for higher education. (Chicago: American Library Association, 2000).

[3] Association of College and Research Libraries. (1998). Information Literacy competency standards for higher education; American Association of School Librarians, 
Information Literacy Standards for Student Learning, American Library Association, http://www.ala.org/ala/aasl/aaslproftools/informationpower /InformationLiteracyStandard s_final.pdf.

[4] Carbery, A., \& Hegarty, N. (2011). Introducing problem-based learning into one-shot information literacy instruction at Waterford Institute of Technology Libraries. SCONUL Focus, 53, 30-33.

[5] Carder, L., Willingham, P., and Bibb, D. (2001). Casebased, problem-based learning: Information literacy for the real world. Research Strategies, 18(3), 181-190.

[6] Donnahan, J. and Stein, B. B. (1999). Assessment: a tool for developing lifelong learners. In B. K. Stripling, Learning and Libraries in an Information Age. Principles and Practice. Littleton: Libraries Unlimited.

[7] Farkas, M. (2012). Participatory technologies, pedagogy 2.0 and Information Literacy. Library Hi Tech, 30(1), 82-94.

[8] Foster, N.F., and Gibbons, S. (2007). Studying students: the undergraduate research project at the University of Rochester. Chicago: Assn of College and Research Libraries.

[9] Ghaith, G. (2010). An exploratory study of the achievement of the twenty-first century skills in higher education. Education and Training, 52(6/7), 489-98.

[10] Huba, M. E., and Freed, J. E. (2000). Learnercentered assessment on college campuses: Shifting the focus from teaching to learning. Boston, MA: Allyn and Bacon.

[11] Niedbala, M. A., and Fogleman, J. (2010). Taking library 2.0 to the next level: using a course Wiki for teaching Information Literacy to honors students. Journal of Library Administration.

[12] Wenger, K. (2014). Problem-Based learning and Information Literacy: a natural partnership. Pennsylvania Libraries: Research and Practice, 2(2), 142-154. 